INTERNATIONAL JOURNAL OF ENVIRONMENT

\title{
CARBON SEQUESTRATION POTENTIAL OF TREES PLANTED ALONG ROADSIDES: A CASE FROM BHOPAL CITY, INDIA
}

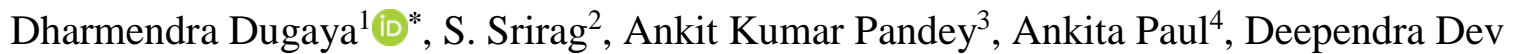 \\ Shukla ${ }^{5}$, Krishna Deo ${ }^{6}$, Nidhi Sharma ${ }^{7}$, Shivani Verma ${ }^{8}$, Shourya Nagaria ${ }^{9}$, Shruti Guhaprasad ${ }^{10}$ \\ and Pradeep Chaudhry ${ }^{11}$ \\ ${ }^{1-11}$ Indian Institute of Forest Management, Bhopal - 462003, Madhya Pradesh, India \\ *Corresponding author: dugayad@iifm.ac.in
}

\begin{abstract}
In the present article, we have discussed one such example from Indian Institute of Forest Management, Bhopal campus where the amount of carbon stored, and carbon dioxide sequestered by the trees along roadside has been estimated. Importance Value Index was calculated separately for each species. Biomass and carbon stock of woody vegetation was assessed using a nondestructive method. Leucaena leucocephala, Schleichera oleosa, Dalbergia paniculata, Acacia catechu and Ficus religiosa recorded high biomass carbon content. The average stem density was 295 stems ha ${ }^{-1}$. Species-wise calculated average $\mathrm{CO}_{2}$ equivalent in the sample observed increasing trend with the increase in girth class from $20 \mathrm{~cm}$ to $60 \mathrm{~cm}$ but showing reduced trend in trees with girth class above $60 \mathrm{~cm}$. The probable reason for reducing trend could be the variation in wood density of species towards the lower value of high girth size species such as Bombax ceiba, Samanea saman, Holoptelea integrifolia, Dalbergia paniculata, Lagerstroemia parviflora and Ficus religiosa. The analysis can be useful for selection of tree species with high wood density for planting in urban areas of central India to adequately mitigate pollution, especially the vehicular pollution. The incorporation of the same in the management plan of the urban green spaces would benefit the optimum utilization of carbon sequestration potential. Moreover, the suitable bamboo species, which is characterized as species of the understory of tropical dry deciduous forests, may be considered for the planting as gap filing and sequestration of carbon in urban areas.

Key words: Urban vegetation, climatic benefits, tropical dry deciduous forests, carbon stock.
\end{abstract}

DOI: http://dx.doi.org/10.3126/ije.v9i2.32537

Copyright @2020 IJE

This work is licensed under a CC BY-NC which permits use, distribution and reproduction in any medium provided the original work is properly cited and is not for commercial purpose 


\section{Introduction}

India is the seventh-largest country in the world. The country is one of the 17 mega bio-diverse countries (Mittermeier and Mittermeier, 2005) occupying just 2.5\% of the world's geographical area but supporting $16 \%$ of the world's human population and $17 \%$ of the livestock population (Mukerji, 2003). Per capita availability of forest and productivity are among the lowest when compared to the world's average, and the immense biotic pressure on the country's forests, making biodiversity conservation a very challenging task (Maan and Chaudhry, 2019). Forest and tree cover in the country is less than one-fourth of the geographical area of the country, which is far behind the national target that strives to have one-third of the total geographical area under forest and tree cover.

Since the industrial revolution, there has been a drastic increase of greenhouse gases (GHG) in the atmosphere, particularly carbon dioxide $\left(\mathrm{CO}_{2}\right)$. Before the industrial revolution, the mean atmospheric $\mathrm{CO}_{2}$ level was approximately 280 ppm, and as of August 2018, the mean $\mathrm{CO}_{2}$ level was 407 ppm (NOAA, 2019). Utilizing the vacant space along major roads and in parks/gardens in the cities is one of the potent options to increase forest and tree cover in the country and help mitigate the adverse effects of climate change. A tree removes (sequesters) carbon dioxide from the atmosphere through photosynthesis, separates the carbon and oxygen atoms and releases oxygen in the atmosphere. In doing so, the tree stores tremendous amount of carbon, and the annual growth (called mean annual increment) increases the storage of carbon in the standing tree but to a threshold level depending upon species to species. Therefore, there is a growing interest in raising roadside tree plantations for capturing and storing atmospheric carbon. It is extremely urgent to reduce fossil fuel emissions and to plant large and healthy trees to maximize the amount of $\mathrm{CO}_{2}$ sequestered by urban trees on roadsides and urban parks. Forests (including urban forests) have received attention in recent years for their potential roles as carbon sinks due to high carbon uptake by fast and young growing plants (Jo, 2002; Nowak and Crane, 2002; Liu and Li, 2012). Young plants sequester more atmospheric carbon as they grow and accumulate biomass within them, whereas ageing trees lose more carbon to atmosphere through respiration, tree cutting and decomposition (Nowak and Crane, 2002; Hai et al., 2015).

Due to urbanization, the condition in the cities as per the environment point of view is at the risk and alarming. However, the roadside plantations/tree avenues in the urban cities play a role not only for improving climatic conditions but significantly contributing to increase area under vegetation in the country. Trees growing along the roadside, either planted or grown naturally, are performing the ecological function not only to reduce the pollution load but also sequester carbon and help mitigate climate change (Da Silva et al., 2010; Singh and Singh, 2015). Additionally, the trees in the urban environment are contributing toward many benefits, e.g. social benefits (recreational opportunities, improving physical/mental health); aesthetic benefits (landscape variations through different colors/textures/forms and densities of plants); climatic benefits (cooling, wind control, air pollution reduction, atmospheric carbon storage, impact on climate) and 
economic benefits (increased property values, tourism, providing fruits and small timber). In accordance with the $74^{\text {th }}$ amendment of the Indian Constitution in 1992, the municipal and urban development authorities are responsible for creating and maintaining parks and other recreational spaces in city areas (Granville, 2009). But, the Urban Local Bodies (ULB) in India have little mandate to combat climate change (Sami, 2017; 2018; Khosla and Bhardwaj, 2018), the climate change rarely features in the development plans of these bodies as per study undertaken by Khosla and Bhardwaj (2018). An effort has been made in the present article to quantify one of the benefits from the trees for mitigating climate change consequences, i.e. the amount of carbon and atmospheric carbon dioxide equivalent stored in the trees planted on roadside in the campus of Indian Institute of Forest Management (IIFM) Bhopal, Madhya Pradesh, India. Nationwide implementation of Green India Mission (GIM) of Government of India as a part of National action plan tackling climate change since last one decade, is supposed to increase above and belowground biomass in 10 million ha of forests (including urban forest ecosystems) resulting in increased carbon sequestration of 43 million tons of $\mathrm{CO}_{2}$ equivalent annually by the end of the year 2020 (Ravindranath and Murthy, 2010). The present study is an attempt to analyze carbon sequestration potential of the trees planted along roadsides and suggest the potential species for high biomass and high efficiency of carbon fixation in urban areas.

\section{Study site}

The study was conducted in the campus of Indian Institute of Management (IIFM), a premier national institute of repute in the field of forestry, environment and natural resource management; which has always laid emphasis on maintaining green cover and raising roadside plantations all over the campus area. The campus of the institute is located between longitude $77^{0} 23^{\prime} 30^{\prime}$ " and latitude $23^{0} 14^{\prime} 30^{\prime}$ ', with highest elevation of altitude $509.8 \mathrm{~m}$ above sea level and is covered under Vindhyan hill range with gentle slopes ranging from $0^{\circ}-5^{\circ}$ and at some places as much as $35^{\circ}$. The site is generally covered by sandstone of Vindhyan formation. Alluvial soil occurs at foothills, and some moisture-loving species have been planted at foothills near main campus gate.

Table 1. Rainfall and mean maximum and mean minimum air temperature of Bhopal

\begin{tabular}{llll}
\hline \multirow{2}{*}{ Year } & $\begin{array}{l}\text { Average annual } \\
\text { rainfall }(\mathrm{mm})\end{array}$ & Mean Maximum & Mean Minimum \\
1999 & 1287.1 & 31.3 & 18.40 \\
2000 & 777 & 31.53 & 18.22 \\
2001 & 885.1 & 32.91 & 18.52 \\
2002 & 878.6 & 31.53 & 16.33 \\
2003 & 1166.2 & 32.08 & 15.95 \\
2004 & 792.9 & 31.13 & 18.14 \\
2005 & 1056.2 & 31.32 & 20.40 \\
2006 & 1883.2 & 31.53 & 19.54 \\
2007 & 885.4 & 32.08 & 18.40 \\
2008 & 679.6 & 31.12 & 19.54 \\
\hline
\end{tabular}




\begin{tabular}{llll}
\hline 2009 & 881 & 31.30 & 18.40 \\
2010 & 597.9 & 31.53 & 18.22 \\
2011 & 1265.5 & 32.30 & 16.36 \\
2012 & 1131.1 & 32.34 & 20.26 \\
2013 & 1263.4 & 31.09 & 19.52 \\
2014 & 725.2 & 32.02 & 19.74 \\
2015 & 998.3 & 32.23 & 19.83 \\
2016 & 1464.1 & 32.64 & 19.64 \\
2017 & 781 & 32.56 & 19.68 \\
2018 & 806.5 & 32.42 & 19.73 \\
2019 & 1681.5 & 31.74 & 19.92 \\
\hline
\end{tabular}

Source: Working Plan, Bhopal Forest Division period 2009-10 to 2018-19; and www.climatechange.mp.gov.in/en/ (accessed on: 22 June 2020)

The average annual rainfall from the year 1999 to 2013 is presented in Table-1. On the basis of long-term rainfall data at Bairagarh and Berasia rain-gauge stations in Bhopal, the average annual rainfall of Bhopal is about $1126.7 \mathrm{~mm}$, while based on IMD station at Bairagarh; the annual normal rainfall of Bhopal is $1260.2 \mathrm{~mm}$ (MoWR, 2013). The minimum air temperature during winter falls to $7^{\circ} \mathrm{C}$ and maximum in summer rises to $45^{\circ} \mathrm{C}$ (Kotwal et al., 2005). The comparisons of the monthwise mean temperature and rainfall for two periods, 1931-1960 and 1971-2000 for Bhopal city shows variations in both parameters. In general, there is an increase in the annual mean minimum temperature by $0.2^{\circ} \mathrm{C}$ and mean maximum temperature by $0.1^{\circ} \mathrm{C}$. Months from December to March have lower mean maximum temperatures and the remaining months have higher temperatures. The annual rainfall also shows an increase of $9.7 \mathrm{~mm}$ and the peak of monsoon season has shifted from July to August (MANIT, 2017).

The soil in the region is derived from upper Vindhyan basalt formation. The Vindhyan structure supports both mixed deciduous and pure teak forests. The soil in the study site is sandy loam on the upper portion and alluvial in the low lying areas. The soil depth is shallow in upper hill portion, where the plant growth is slow, whereas in the lower hillock side, the soil depth is medium and generally support luxuriant vegetation.

The institute is located on a hilly patch covering 80.64 ha of the area with tropical dry deciduous forest comprising mainly of tree species like Lannea coromandelica, Anogeissus latifolia, Wrightia tinctoria, Lagerstroemia parviflora, Diospyros melanoxylon, Acacia catechu, Schleichera oleosa, Zizyphus xylopyra, Sterculia urens, Bombax ceiba, Ficus religiosa, Dalbergia paniculata, Leucaena leucocephala, Azadiracta indica, Jatropha curcas, Dendrocalamus strictus and few associated species. About one-third of area (26.46 ha) of the campus (Table-2 and Figure1) is covered with grasses, few scrubs and medium sized tree species. Important grasses include Apluda mutica, Aristida setacea, Axonopus compressus, Cenchrus ciliaris, Cenchrus setigerus, Chrysopogon fulvus, Cynodon dactylon, Dichanthium annulatum, Digitaria setigera, 
Heteropogon contortus, Panicum notatum, Saccharum spontaneum, Themeda quadrivalvis and Themeda triandra (Kotwal et al., 2005).

Table 2. Categorization of study area according to forest density

\begin{tabular}{llll}
\hline S. No. & Category of area & Canopy density & Area (ha) \\
1 & Dense forest & 0.65 to 0.8 & 19.61 \\
2 & Moderately dense forest & 0.45 to 0.65 & 29.36 \\
3 & Grassland and scrub land & 0.15 to 0.45 & 26.46 \\
4 & Built-up area & Below 0.15 & 5.21 \\
\hline
\end{tabular}

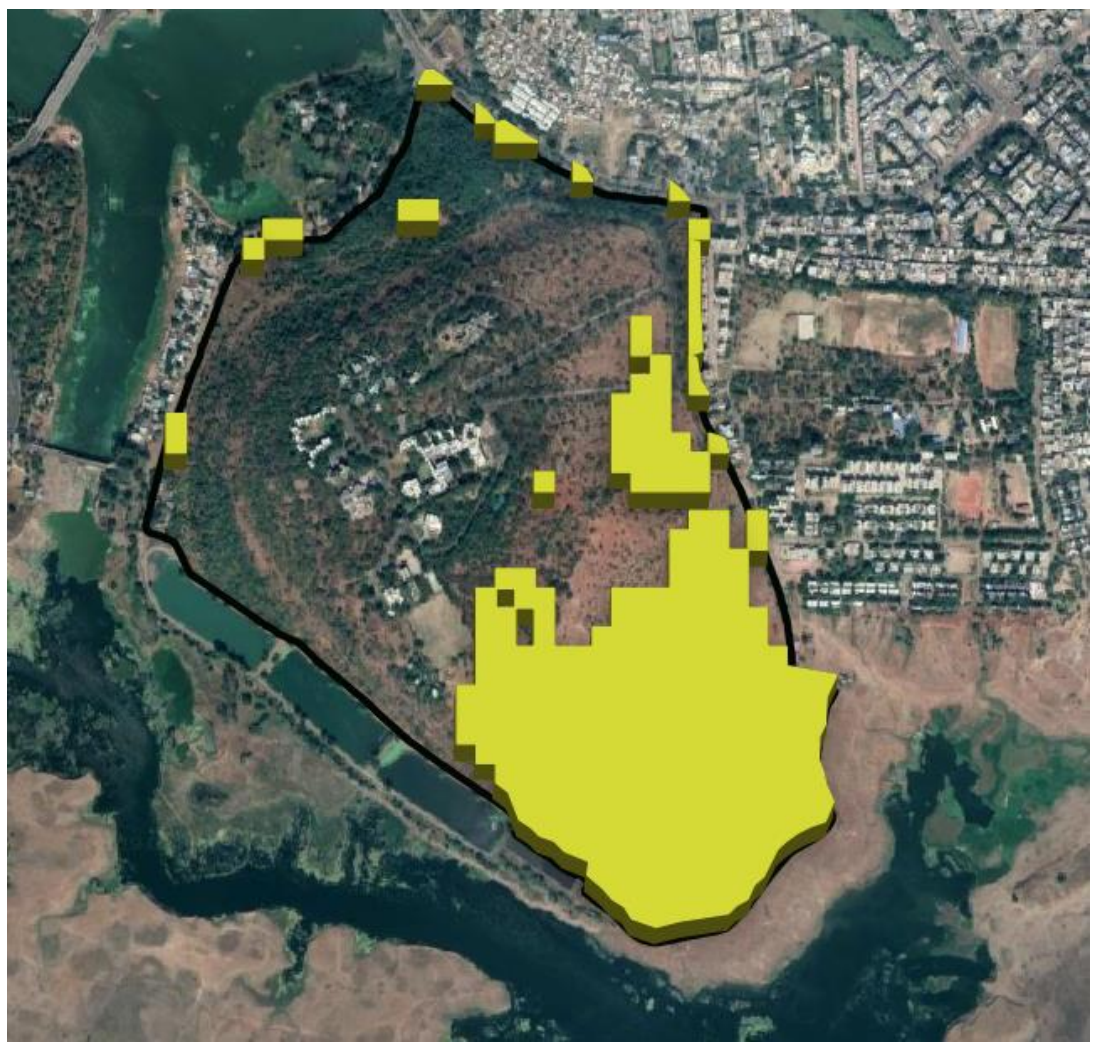

Figure 1. Grassland and scrub patch shown in yellow color

\section{Materials and methods}

A length of about 763 meters along the roads and 4 meters width both sides of the roads was surveyed by the students of Post Graduate Diploma in Forestry Management (PGDFM) and main authors of this article in the institute during January/February 2020 months (Figure 2). 

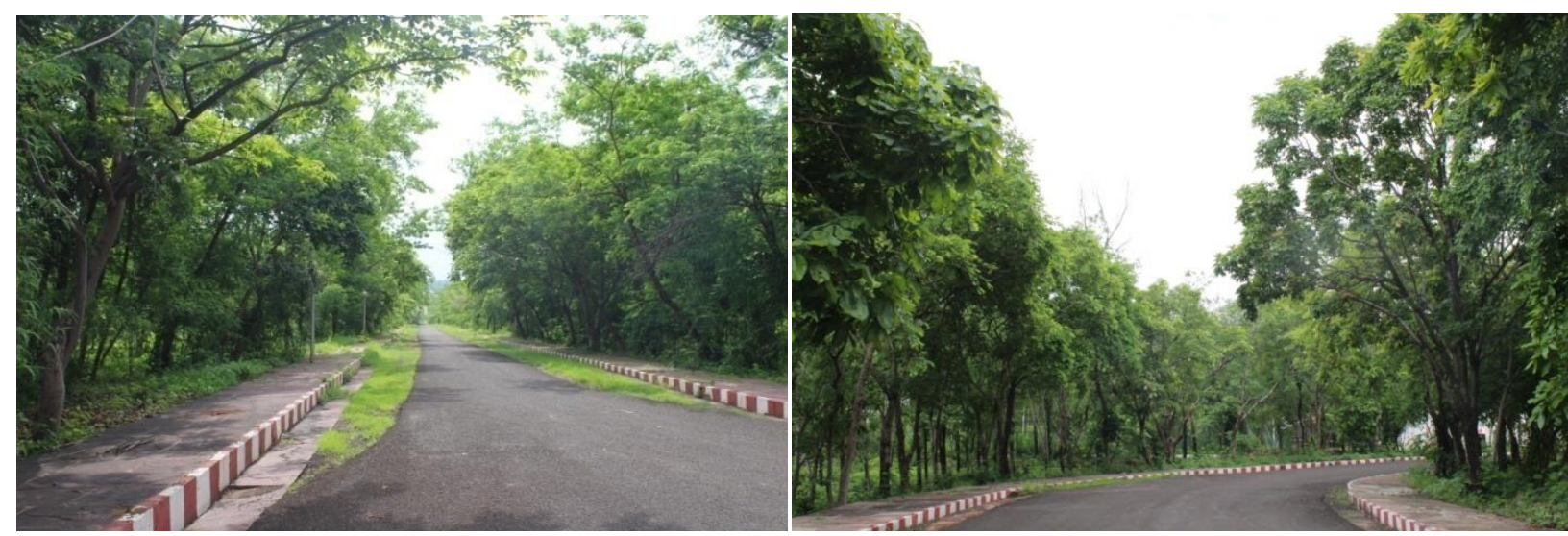

Figure 2. A view of roadside plantation comprising different tree species at the study site.

Girth at breast height $(\mathrm{GBH})$ of the trees above $20 \mathrm{~cm}$ was measured with measuring tape and overall height was measured with Christan's hypsometer. Bamboo clump size, number of culms per clump and average height of culms was also recorded with a measuring rod. Volume of each tree was estimated using standard volume equations devised by Forest Survey of India, Dehradun or by form factor formula method where volume equations were not available. The volume was multiplied by the density of the corresponding tree species to get the above-ground biomass in Mega Grams. This value was multiplied by a factor 0.45 to get the above-ground carbon stock in the trees. The total area surveyed comes out to be 0.6104 hectares $\left(763 \times 8=6104 \mathrm{~m}^{2}\right)$. The area calculated from covered road length of $763 \mathrm{~m}$ with a width of $4 \mathrm{~m}$ on one-side of the road, comes out as $(763 \times 4)=3052 \mathrm{~m}^{2}$. The area covered for both sides of the road would be double of the area calculated for one side.

\section{Data analysis}

A species, which attains the highest importance value in the site, is the dominant one and the species with variation in the values indicate respective importance of species in plant community of study site. In order to determine the proportional representation of each species in the given plant community, values of relative cover, relative density and relative frequency were computed. An Importance value (IV) for each species is derived from the combined contribution of the relative cover, relative density and relative frequency of each species in the community.

Biomass and Carbon stock of woody vegetation were assessed using a non-destructive method. A brief description of the used formulae for tree carbon estimation in the analysis is given below: Diameter at Breast Height $(\mathrm{DBH})=$ Girth at Breast Height $/ \pi$ meters

- Volume $\left(\mathrm{m}^{3}\right)=$ Basal area $\mathrm{x}$ Height $\mathrm{x}$ Form Factor

- Above Ground Biomass (AGB) = Volume x Density Mg (where, $1 \mathrm{Mg}$ or Mega gram $=1$ ton)

- Carbon Stock $(\mathrm{Mg})=\mathrm{AGB} \times 0.45$

- $\mathrm{CO}_{2}$ equivalent $(\mathrm{Mg})=\frac{44}{12} x$ CarbonStock 
- Basal Area $\left(\mathrm{m}^{2}\right)=\frac{\pi}{4} x \mathrm{DBH}^{2}$

The estimated above-ground biomass $(\mathrm{kg})$ of the trees was converted by a factor of 0.45 to obtain the amount of carbon for the tree species. The equivalent carbon dioxide was calculated from the carbon stock by applying a conversion factor of 3.36 (molar ratio of carbon dioxide to carbon, 44/12) (Stoffberg et al., 2010).

\section{Results and discussion}

A complete enumeration of all the trees within four-meter width on both sides of the road for a distance of $763 \mathrm{~m}$ resulted in data for 472 individual trees. The recorded tree species along the roadside are given in Tables 3 and 4 . We found 21 different species (besides two bamboo species) belonging to 16 families in the survey area.

Among the twenty-one plant species obtained from the measurements, Leucaena leucocephala, Lannea coromandelica, Azadiracta indica, Schleichera oleosa and Jatropha curcas were the most prominent species based on the stem density, relative frequency and the value of Importance value index. However, as per the calculated basal area, the prominent species were Ficus religiosa, Holoptelia integrifolia, Dalbergia paniculata, Hardwinkia binata and Lagerstroemia parviflora. This might be due to species distribution as per the observed frequency. Leucaena leucocephala, Schleichera oleosa, Dalbergia paniculata, Acacia catechu and Ficus religiosa species recorded for high biomass carbon content (Table-3).

Leguminosae was the most dominant family, accounting for $14.29 \%$ of all recorded species and $48 \%$ of total estimated biomass carbon. Average stem density was 295 stems ha $^{-1}$; average DBH of $16.13 \mathrm{~cm}$ (range: $3.5 \mathrm{~cm}-33.1 \mathrm{~cm}$ ) and average basal area of $0.022 \mathrm{sq} \mathrm{m}$ (range: $0.001 \mathrm{sq} \mathrm{m} \mathrm{-}$ 0.049 sq m) were recorded. Species diversity H' (Shannon's diversity index) was found as 0.864 . This index ranges between 0.83 and 4.1 ; the reported range for this index for the forests of the Indian sub-continent. Therefore, its value is within range but on the lower side (Jha and Singh, 1990; Visalakshi, 1995; Sahu et al., 2012; Panda et al., 2013). 
Table 3. Recorded tree species along the roadside in the campus of Indian Institute of Forest Management (IIFM)

\begin{tabular}{|c|c|c|c|c|c|c|c|c|c|c|c|}
\hline $\begin{array}{l}\text { S. } \\
\text { No. }\end{array}$ & Species & $\begin{array}{l}\mathrm{RD} \\
(\%)\end{array}$ & $\begin{array}{l}\mathrm{RF} \\
(\%)\end{array}$ & $\begin{array}{l}\mathrm{RC} \\
(\%)\end{array}$ & IVI & $\begin{array}{l}\text { Basal } \\
\text { Area }\left(\mathrm{m}^{2}\right)\end{array}$ & $\begin{array}{l}\text { Volume } \\
\left(\mathrm{m}^{3}\right)\end{array}$ & $\begin{array}{l}\text { AGB } \\
(\mathrm{Mg})\end{array}$ & $\begin{array}{l}\text { Carbon } \\
\text { Stock } \\
(\mathrm{Mg})\end{array}$ & $\begin{array}{l}\mathrm{CO}_{2} \\
\text { Equivalent } \\
(\mathrm{Mg})\end{array}$ & $\mathrm{BCC}(\%)$ \\
\hline 1 & Acacia catechu & 3.52 & 7.21 & 0.37 & 11.10 & 0.030 & 0.14634 & 2.318 & 1.0431 & 3.8246 & 8.4123 \\
\hline 2 & Annona squamosa & 0.19 & 0.51 & 0.01 & 0.71 & 0.001 & 0.00144 & 0.0009 & 0.0004 & 0.0015 & 0.0032 \\
\hline 3 & Anogeissus latifolia & 0.58 & 1.54 & 0.44 & 2.57 & 0.021 & 0.10445 & 0.2381 & 0.1072 & 0.3929 & 0.8645 \\
\hline 4 & Azadiracta indica & 5.66 & 8.24 & 0.20 & 14.11 & 0.011 & 0.02899 & 0.5802 & 0.2611 & 0.9573 & 2.1057 \\
\hline 5 & Bombax ceiba & 0.97 & 2.57 & 1.11 & 4.67 & 0.032 & 0.17744 & 0.2928 & 0.1317 & 0.4831 & 1.0620 \\
\hline 6 & Dalbergia paniculata & 2.93 & 3.54 & 4.82 & 11.35 & 0.046 & 0.24443 & 2.3465 & 1.0559 & 3.8717 & 8.5155 \\
\hline 7 & Diospyros melanoxylon & 1.56 & 3.60 & 0.89 & 6.06 & 0.016 & 0.05442 & 0.2961 & 0.1332 & 0.4885 & 1.0742 \\
\hline 8 & Ficus religiosa & 2.34 & 5.67 & 4.10 & 12.11 & 0.049 & 0.28372 & 1.3278 & 0.5975 & 2.1909 & 4.8187 \\
\hline 9 & Hardwinkia binata & 0.97 & 5.57 & 1.36 & 4.99 & 0.039 & 0.13998 & 0.5109 & 0.2299 & 0.843 & 1.8541 \\
\hline 10 & Holoptelia integrifolia & 0.39 & 1.03 & 0.65 & 2.07 & 0.047 & 0.25615 & 0.3586 & 0.1614 & 0.5917 & 1.3016 \\
\hline 11 & Jatropha curcas & 10.57 & 7.73 & 3.01 & 21.29 & 0.008 & 0.02080 & 1.0895 & 0.4903 & 1.7977 & 3.9541 \\
\hline 12 & Lagerstroemia parviflora & 0.39 & 1.03 & 0.488 & 1.91 & 0.035 & 0.17332 & 0.2149 & 0.0967 & 0.3546 & 0.7799 \\
\hline 13 & Lannea coromandelica & 5.8 & 10.82 & 3.35 & 20.03 & 0.016 & 0.05391 & 0.8733 & 0.393 & 1.4409 & 3.1694 \\
\hline 14 & Leucaenaleucocephala & 24.8 & 14.94 & 15.06 & 54.82 & 0.017 & 0.08697 & 8.8366 & 3.9765 & 14.5804 & 32.0693 \\
\hline 15 & Samania saman & 4.10 & 4.12 & 4.54 & 12.7 & 0.031 & 0.09584 & 0.9057 & 0.4076 & 1.4945 & 3.2872 \\
\hline 16 & Santalum album & 2.53 & 5.15 & 0.54 & 8.2 & 0.006 & 0.02154 & 0.2352 & 0.1058 & 0.3881 & 0.8532 \\
\hline 17 & Schleichera oleosa & 11.5 & 8.24 & 10.29 & 30.06 & 0.025 & 0.11620 & 6.5818 & 2.9618 & 10.86 & 23.8861 \\
\hline 18 & Sterculia urens & 2.73 & 4.63 & 0.39 & 7.7 & 0.004 & 0.00955 & 0.0896 & 0.0403 & 0.1478 & 0.3250 \\
\hline 19 & Tectona grandis & 0.195 & 0.51 & 0.01 & 0.72 & 0.002 & 0.00156 & 0.0013 & 0.0006 & 0.0022 & 0.0048 \\
\hline 20 & Wrightia tinctoria & 0.39 & 1.03 & 0.26 & 1.68 & 0.019 & 0.07800 & 0.117 & 0.0526 & 0.193 & 0.4242 \\
\hline \multirow[t]{2}{*}{21} & Zizyphus xylopyra & 2.53 & 4.63 & 1.81 & 8.99 & 0.020 & 0.05728 & 0.633 & 0.2848 & 1.0444 & 2.2968 \\
\hline & & & & & & & Total & 27.555 & 12.3997 & 45.4657 & 100 \\
\hline
\end{tabular}

RD: Relative Density; RF: Relative Frequency; RC: Relative Cover; IVI: Importance Value Index; AGB: Above Ground Biomass;

BCC: Biomass Carbon Content; m: Meter; Mg: Mega gram 
Table 4. Above Ground Biomass (AGB), Carbon stock and $\mathrm{CO}_{2}$ Equivalent of enumerated Bamboo on roadside in Indian Institute of Forest Management (IIFM) campus

\begin{tabular}{|c|c|c|c|c|c|c|c|c|c|}
\hline $\begin{array}{l}\text { S. } \\
\text { No. }\end{array}$ & Species & $\begin{array}{l}\text { Average Clump } \\
\text { size (Periphery - } \\
\mathrm{cm})\end{array}$ & $\begin{array}{l}\text { Average } \\
\text { Culm } \\
\text { Height (m) }\end{array}$ & $\begin{array}{l}\text { Cumulative } \\
\mathrm{DBH}(\mathrm{m})\end{array}$ & $\begin{array}{l}\text { Basal } \\
\text { Area } \\
\left(\mathrm{m}^{2}\right)\end{array}$ & $\begin{array}{l}\text { Volume } \\
\left(\mathrm{m}^{3}\right)\end{array}$ & $\begin{array}{l}\text { AGB } \\
(\mathrm{Mg})\end{array}$ & $\begin{array}{l}\text { Carbon } \\
\text { Stock } \\
(\mathrm{Mg})\end{array}$ & $\begin{array}{l}\mathrm{CO}_{2} \\
\text { Equivalent } \\
(\mathrm{Mg})\end{array}$ \\
\hline 1 & $\begin{array}{l}\text { Bambusa } \\
\text { vulgaris }\end{array}$ & 17.500 & 6.000 & 0.056 & 0.002 & 0.00731 & 0.0044 & 0.0020 & 0.0072 \\
\hline \multirow[t]{2}{*}{2} & $\begin{array}{l}\text { Dendrocalamus } \\
\text { strictus }\end{array}$ & 103.857 & 3.588 & 0.331 & 0.086 & 0.2156 & 9.9611 & 4.4825 & 16.435 \\
\hline & & & & & & Total & 9.9655 & 4.4845 & 16.442 \\
\hline
\end{tabular}

Average Clump Size of Dendrocalamus strictus = nine culm

In addition to tree species, two bamboo species of woody culm, Bambusa vulgaris and Dendrocalamus strictus were also observed in the study area. The species are sympodial or clump-forming bamboo with 1 and 77 clumps of Bambusa vulgaris and Dendrocalamus strictus, respectively. The calculated Carbon Stock (Mg) and $\mathrm{CO}_{2}$ Equivalent $(\mathrm{Mg}$ ) recorded for Bambusa vulgaris and Dendrocalamus strictus as 0.002, 0.0072; and 4.482, 16.435 respectively (Table-4). Calculated overall above-ground biomass (AGB) in the study area of 0.6104 ha was obtained as 37.51 Mega gram which converts to $61.95 \mathrm{Mg} \mathrm{ha}^{-1}$ (on area basis, i.e. ha ${ }^{-1}$ ) and 49.16 $\mathrm{Mgkm}^{-1}$ (on unit length basis, i.e. running $\mathrm{km}$ ), whereas carbon stock was found to be $16.883 \mathrm{Mega}$ gram over the surveyed length converting to $27.88 \mathrm{Mgha}^{-1}$ and $22.12 \mathrm{Mgkm}^{-1}$. Overall $\mathrm{CO}_{2}$ equivalent was estimated as 61.91 Mega gram or 102.21 $\mathrm{Mgha}^{-1}$ and 81.14 $\mathrm{Mg} \mathrm{km}^{-1}$ (Tables 3, 4 and 5). Kiran and Shah (2011) found $\mathrm{CO}_{2}$ equivalent sequestered as $73.59 \mathrm{Mgkm}^{-1}$ for the different roads for Vadodra city, Gujarat. In contrast, Desai and Nandikar (2012) found $\mathrm{CO}_{2}$ equivalent sequestered as $54.36 \mathrm{MgKm}^{-1}$ for the different roads for Kohlapur city, Maharashtra. Carbon dioxide sequestered by plantation on roadside is at the higher side in the present study than that of Vadodara and Kohlapur cities of India. The probable reason for high $\mathrm{CO}_{2}$ equivalent in the study area may be due to the denser plantation at IIFM campus at Bhopal which is situated in the more isolated safe and secure environment than on other polluted roads in industrialized cities like Kohlapur and Vadodara. However, our results are on the lower side than those obtained in two studies conducted in urban forest ecosystems of Delhi as depicted from the study by Meena et al. (2019) for standing biomass carbon content as $41.87 \mathrm{Mg} \mathrm{ha}^{-1}$ and $49.58 \mathrm{Mg} \mathrm{ha}^{-1}$ as reported by Tripathi and Joshi (2015). These two studies were conducted in Delhi ridge natural urban forest ecosystem and human-made urban park/gardens of Delhi respectively, where stem density and average DBH were on the higher side than the present study. Comparing with other countries studies from neighboring Bangladesh, our results are on the lower side, from the above-ground road side biomass carbon stock as $165.81 \mathrm{Mg} \mathrm{C} \mathrm{ha}^{-1}$ in south-western districts of Bangladesh (Rahman et al., 2015) with Jaman et al., (2020) estimating above-ground roadside biomass carbon stock as $109.53 \mathrm{Mg} \mathrm{C} \mathrm{ha}^{-1}$ for Dhaka city roadside plantations and Islam et al., (2017) estimating for institutional plantations in the country as $150 \mathrm{Mg} \mathrm{C} \mathrm{ha}^{-1}$. Higher basal area and plantation 
density, good rainfall and high relative humidity are the probable reasons for higher side results in Bangladesh studies (Kabir and Webb, 2007). Results obtained in the current study are also lower than a study conducted in Muscat, Oman where above-ground carbon stock for roadside plantations was $991.94 \mathrm{Mg} \mathrm{Cha}^{-1}$. (Amoatey and Sulaiman, 2019). In Oman study average DBH for 373 roadside trees was above $50 \mathrm{~cm}$ in comparison to $16.13 \mathrm{~cm} \mathrm{DBH}$ in the present study, justifying more carbon stock in Muscat, Oman study. However our results are somewhat nearer to the studies conducted in China, Australia and USA, e.g. above-ground roadside biomass carbon stock of $34 \mathrm{Mg} \mathrm{Cha}^{-1}$ on roadsides of Shenyang China (Liu and Li, 2012); $20.3 \mathrm{Mg} \mathrm{Cha}^{-1}$ for the trees on Highway no. 1 of Taiwan (Wang, 2011), $11.71+/-3.57 \mathrm{Mg} \mathrm{C}^{-1}{ }^{-1}$ on Australian roadsides; 45.49 $\mathrm{Mg} \mathrm{C} \mathrm{ha}^{-1}$ in Butter street and 22.29 $\mathrm{Mg} \mathrm{Cha}^{-1}$ in Penn street of Kingston, Pensylvania, USA (Keating et al., 2005).

Table 5. Above Ground Biomass (AGB), Carbon Stock and $\mathrm{CO}_{2}$ equivalent per ha of each species

\begin{tabular}{lllll}
\hline $\mathrm{S}$. & Species & $\mathrm{AGB}$ & $\begin{array}{l}\text { Carbon stock } \\
(\mathrm{Mg})\end{array}$ & $\begin{array}{l}\mathrm{CO}_{2} \text { equivalent } \\
(\mathrm{Mg})\end{array}$ \\
1 & Acacia catechu & 3.798 & 1.709 & 6.266 \\
2 & Annona squamosa & 0.001 & 0.001 & 0.002 \\
3 & Anogeissus latifolia & 0.390 & 0.176 & 0.644 \\
4 & Azadiracta indica & 0.951 & 0.428 & 1.568 \\
5 & Bombax ceiba & 0.480 & 0.216 & 0.791 \\
6 & Dalbergia paniculata & 3.844 & 1.730 & 6.343 \\
7 & Diospyros melanoxylon & 0.485 & 0.218 & 0.800 \\
8 & Ficus religiosa & 2.175 & 0.979 & 3.589 \\
9 & Hardwinkia binata & 0.837 & 0.377 & 1.381 \\
10 & Holoptelia integrifolia & 0.587 & 0.264 & 0.969 \\
11 & Jatropha curcas & 1.785 & 0.803 & 2.945 \\
12 & Lagerstroemia parviflora & 0.352 & 0.158 & 0.581 \\
13 & Lannea coromandelica & 1.431 & 0.644 & 2.361 \\
14 & Leucaena leucocephala & 14.477 & 6.515 & 23.887 \\
15 & Samanea saman & 1.484 & 0.668 & 2.448 \\
16 & Santalum album & 0.385 & 0.173 & 0.636 \\
17 & Schleichera oleosa & 10.783 & 4.852 & 17.792 \\
18 & Sterculia urens & 0.147 & 0.066 & 0.242 \\
19 & Tectona grandis & 0.002 & 0.001 & 0.004 \\
20 & Wrightia tinctoria & 0.192 & 0.086 & 0.316 \\
21 & Zizyphus xylopyra & 1.037 & 0.467 & 1.711 \\
& & 45.622 & 20.530 & 75.277 \\
22 & Bambusa vulgaris & 0.007 & 0.003 & 0.012 \\
23 & Dendrocalamus strictus & 16.319 & 7.344 & 26.926 \\
& & 16.326 & & 26.938 \\
\hline
\end{tabular}


It is observed that Leucaena leucocephala, Schleichera oleosa, Dalbergia paniculata, Acacia catechu and Ficus religiosa are the top five plant species which are responsible for maximum carbon storage along the roadsides (Table-3). Dendrocalmus strictus is also a very useful species (a solid bamboo) as it is found to sequester $\mathrm{CO}_{2}$ equivalent as $26.92 \mathrm{Mg} \mathrm{Cha}^{-1}$, which is higher than other tree species. Due to its fast growth, it has the potential to store carbon more efficiently which makes it a viable option for mitigating climate change (Kaushik et al., 2015). D. strictus is also a better option, compared to a few other tropical and temperate plantation species as far as the magnitude of carbon storage in a given time was concerned (Singh et al., 2006). Therefore, institute management has laid more emphasis on a bamboo plantation along roadsides of the campus during the last five years. Leucaena leucocephala (Subabul) is a very fast-growing tree species coming naturally in the institute. The species produces large number of pods and seeds in the months of January/February, which requires minimum amount of moisture and quality soil for the regeneration and survival. The major disadvantage of this species includes its suppressing nature of seedlings of other species to thrive. Hence, due precautions have to be taken for further proliferation of this species along roadsides in the campus. However, the health of Samanea saman trees are a matter of concern as dead, dying, and diseased trees are visible on roadsides. A detailed examination by a team of foresters, pathologists and entomologists are required for underlining the causes of its poor survival. Actually, this species requires deep loamy soil and high rainfall, whereas available soil is too shallow and rocky to support healthy trees of this particular species. This seems to be the most probable reason for the failure of this particular species and future plantation of this species should be avoided on the campus.

The Schleichera oleosa (Kusum) tree has got attractive foliage, especially pink-colored new and young leaves during late winters, making it an attractive avenue plantation species. Chandigarh city, the joint capital of Punjab and Haryana, has a sizeable number of this tree species along roadsides in various sectors. Indian Institute of Forest Management (IIFM) has also laid more emphasis on this species for taking-up as one of the plantation species along the roadsides.

In managed urban or roadside plantations, tree managers try to maintain a mixed stand of young and old-trees. However, the fact remains as the trees with high Diameter at Breast Height (DBH) may store about 1000 times more carbon than trees of low DBHs (Stoffberg et al., 2010). Thus, urban planning should consider planting of high biomass detaining trees to ensure maximum removal of anthropogenic $\mathrm{CO}_{2}$ (Yaoet al., 2015). Further, our analysis indicates that the calculated $\mathrm{CO}_{2}$ equivalent observed is increasing with the increase in girth class from $20 \mathrm{~cm}$ to $60 \mathrm{~cm}$ and showing reduced trend in trees with girth class above $60 \mathrm{~cm}$ in the study area. This might be due to the variation in wood density of plant, i.e. Bombax ceiba, Samanea seman, 
Holoptelea integrifolia, Dalbergia paniculata, Lagerstroemia parviflora, Ficus religiosa. The analysis would facilitate in selection of tree species with high wood density for planting in urban areas. The incorporation of the same in the management plan of the urban green would benefit the optimum utilization of carbon sequestration potential.

\section{Conclusion}

The work contributes in filling the gap and orients the Urban Local Bodies (ULBs) for consideration of the selection of native tree species with high biomass and high efficiency of carbon fixation which is highly recommended in plantation programs along roadsides and institutional areas in central India. This may not only adequately provide help in mitigating pollution, specially the vehicular pollution but also effectively addresses the mandate of Government of India to bring 33\% of its geographical area under forest cover by 2022.

\section{Conflict of interest}

It is hereby declared that no competing interest exists among the authors and the authors declare no potential conflict of interest.

\section{Contribution of authors}

\section{Dharmendra Dugaya}

Data analysis, writing paper and capturing photographs.

\section{S. Srirag}

Data collection from field, compilation, analysis and capturing photographs.

\section{Ankit Kumar Pandey}

Data collection from field, compilation, literature review and analysis.

\section{Ankita Paul}

Data collection from field, compilation and analysis.

\section{Deependra Dev Shukla}

Data collection from field, compilation and analysis.

\section{Krishna Deo}

Data collection from field, compilation and analysis.

\section{Nidhi Sharma}

Data collection from field, compilation and analysis.

\section{Shivani Verma}


Data collection from field, compilation and analysis.

\section{Shourya Nagaria}

Data collection from field, compilation and analysis.

\section{Shruti Guhaprasad}

Data collection from field, compilation, literature review and analysis.

\section{Pradeep Chaudhry}

Assisting writing article, literature review and overall supervision in field for data collection.

\section{Acknowledgement}

The authors are thankful to the editor of the International Joumal of Environment and anonymous editor/reviewer(s) for the valuable and constructive comments for making the research article meaningful.

\section{References}

Amoatey, P. and Sulaiman, H., 2019. Quantifying carbon storage potential of urban plantations and landsapes in Muscat, Oman. Environment, Development and Sustainability. Doi: 10.1007/s10668-019-00556-5

Da Silva, A.M., Alves, B.C. and Alves, S.H., 2010. Roadside vegetation: estimation and potential for carbon sequestration. iForest, 3:124-129. Doi: 10.3832/ifor0550-003

Desai, T.B. and Nandikar, M., 2012.Impact of urbanization on avenue trees and its role in carbon sequestration: a case study in Kohlapur city. International Journal of Environmental Sciences, 3(1), 481-486. Doi:10.6088/ijes.2012030131046

Granville, A., 2009. The Indian Constitution Cornerstone of a Nation. Oxford University Press, New Delhi.

Islam, M., Deb, G.P., and Rahman, M., 2017. Forest fragmentation reduced carbon storage in a moist tropical forest in Bangladesh: Implications for policy development. Land Use Policy, 65, 15. Doi: 10.1016/j.landusepol.2017.03.025

Hai, V.D., Do, T.V., Trieu, D.T., Sato, T. and Kozan, O., 2015. Carbon stocks in tropical evergreen broadleaf forests in Central Highland, Vietnam. International Forestry Review, 17(1), 20-29. https://www.jstor.org/stable/24310649 (accessed on: 15 March 2020).

Jaman, S., Zhang, X. and Islam, F., 2020. Carbon storage and tree diversity in the urban vegetation of Dhaka city, Bangladesh: a study based on intensive field investigation. Arboricultural Journal: The International Journal of Urban Forestry. Doi:10.1080/03071375.2020.1755186

Jha, C.S. and Singh, J.S., 1990. Composition and dynamics of dry tropical forest in relation to soil. Journal of Vegetation Science, 1, 609-614. Doi: 10.2307/3235566 
Jo, H., 2002. Impacts of urban green space on offsetting carbon emissions for middle Korea. Journal of Environmental Management, 64(2), 115-126. Doi: 10.1006/jema.2001.0491

Kabir, M.E., Webb, E.L., 2007. Can home gardens conserve biodiversity in Bangladesh? Biotropica 40(1), 95-103. Doi:10.1111/j.1744-7429.2007.00346.x

Kaushi, S., Singh, Y.P., Kumar, D., Thapliyal, M. and Barthwal, S., 2015. Bamboos in India. ENVIS centre on Forestry. National Forest Library and Information Centre. FRI, Dehradun, India.

Keating, B., Roveda, E., Smith, M., Klemow, K., Toothill, W., Troy, M., 2005. Inventorying and Assessing the Values of Urban Trees in Kingston, PA using CITY green Biology Department. Wilkes University, Wilkes-Barre., PA, p. 18766.

Khosla, R. and Bhardwaj, A., 2018. Urbanization in the time of climate change: Examining the response of Indian cities. Wires Climate Change. Doi: $10.1002 /$ wcc.560

Kiran, G.S. and Kinnary, S., 2011. Carbon sequestration by urban trees on roadsides of Vadodra city. International Journal of Engineering Sciences and Technology, 3(4), 3066-70. https://www.researchgate.net/profile/Sandhya_Garge/publication/267771547_Carbon_sequestration _by_urban_trees_on_roadsides_of_Vadodara_city/links/556d49df08aeab777223219f.pdf (accessed on: 4 April 2020).

Kotwal, P.C., Dugaya, D. and Mishra, R.P., 2005. Biodiversity of IIFM campus, Indian Institute of Forest Management Bhopal.

Liu, C., and Li, X., 2012. Carbon storage and sequestration by urban forests in Shenyang, China. Urban Forestry and Urban Greening, 11(2), 121-128. Doi: 10.1016/j.ufug.2011.03.002

Maan, J.S. and Chaudhry, P., 2019. People and protected areas: some issues from India. Animal Biodiversity and Conservation, 42(1), 79-90. Doi: 10.32800/abc.2019.42.0079

MANIT., 2017. Assessing the Impacts of Climate Change on Urban Sector in Madhya Pradesh. Maulana Azad National Institute of Technology, Bhopal. Pp 22. https://www.devalt.org/images/L2_ProjectPdfs/(12)AssessingImpactsofCC.pdf?Oid=147 (accessed on: 25 June 2020).

MoWR., 2013, District ground-water information booklet - Bhopal district. Ministry of Water Resources, Bhopal. 7 pp. http://cgwb.gov.in/District_Profile/MP/Bhopal.pdf (accessed on: 25 June 2020).

McPherson, E.G., 2007. Benefit- Based Tree Valuation. Arboriculture and Urban Forestry. 33(1), 111.https://www.fs.fed.us/psw/publications/mcpherson/psw_2007_mcpherson002.pdf (accessed on: 4 April 2020). 
Meena, A., Bidalia, A., Hanief, M., Dinakaran, J. and Rao, K.S., 2019. Assessment of above and below ground carbon pools in a semi-arid forest ecosystem of Delhi, India. Ecological Processes, 8(8), 1-11. https://link.springer.com/article/10.1186/s13717-019-0163-y (accessed on: 4 April 2020).

Mittermeier, R.A., Mittermeier, C.G., 2005. Mega-diversity: Earth's Biologically Wealthiest Nations. Cemex, Mexico.

Mukerji, A.K., 2003. Forest Policy Reforms in India - Evolution of the Joint Forest Management Approach. World Forestry Congress, Québec City, Canada, 0729-C1.

NOAA., 2019. Trends in Atmospheric Carbon Dioxide. https://www.esrl.noaa.gov/gmd/ccgg/trends/index.html (accessed on: 4 April 2020).

Nowak, D.J. and Crane, D.E., 2002. Carbon storage and sequestration by urban trees in the USA. Environmental Pollution, 116, 381-389. https://doi.org/10.1016/S0269-7491(01)00214-7

Panda, P.C., Mahapatra, A.K., Acharya, P.K., Debata, A.K., 2013. Plant diversity in tropical deciduous forests of Eastern Ghats, India: A landscape level assessment. International Journal of Biodiversity Conservation 5 (10), 625-639. Doi: 10.5897/IJBC2013.0581x

Rahman, M.M., Kabir, M.E., Akon, A.S.M.J.U. and Ando, K., 2015. High carbon stocks in roadside plantations under participatory management in Bangladesh. Global Ecology and Conservation, 3, $412-$ 423.

Ravindranath, N.H. and Murthy, I.K., 2010. Greening India Mission. Current Science, 99(4), 390-395. https://www.jstor.org/stable/24109567?seq=1 (accessed on: 9 June 2020).

Sahu, S.C., Dhal, N.K., Mohanty, R.C., 2012. Tree species diversity, distribution and population structure in a tropical dry deciduous forest of Malyagiri Hill ranges, Eastern Ghats, India. Tropical Ecology 53(2), 163-168.

Sami, N., 2017. Multi-level climate change planning: Scale, capacity and the ability for local action. In S. Moloney, H. Fünfgeld, and Granberg (Eds.), Local action on climate change: Opportunities and constraints (pp. 92-110). Abingdon, Oxon, England: New York, NY: Routledge.

Sami, N., 2018. Localizing environmental governance in India. In A. Luque-Ayala, S. Marvin, and H. Bulkeley (Eds.), Rethinking urban transitions: Politics in the low carbon city (pp. 164-182). Abingdon, Oxon, England: New York, NY: Routledge.

Singh, P., Dubey, P. and Jha, K.K., 2006. Bamboo production and carbon storage at harvest age in superior Dendrocalamus strictus Nees. Plantation in dry deciduous forest region of India. Indian Journal of Forestry, 29(4), 353-360.

Singh, U.S. and Chandra, J., 2020. Land degradation in India and climate change. Me and My Earth, an Environmental magazine, 4(14), 05-08. 
Singh, K. and Singh, G., 2015. Roadside vegetation diversity of Jodhpur district and its role in carbon sequestration and climate change mitigation. Advances in Forestry Science, 2(2), 23-33. https://doi.org/10.34062/afs.v2i2.2157

Stoffberg, G.H., van Rooyen, M.W., van der Linde, M.J. and Groeneveld, H.T., 2010. Carbon sequestration estimates of indigenous street trees in the City of Tshwane, South Africa. Urban Forestry and Urban Greening, 9(1), 9-14. https://doi.org/10.1016/j.ufug.2009.09.004

Tripathi, M. and Joshi, H., 2015. Carbon flow in Delhi urban forest ecosystems. Annals of Biological Research, 6(8), 13-17.Available online at www.scholarsresearchlibrary.com (accessed on: 5 April 2020).

Visalakshi, N., 1995. Vegetation analysis of two tropical dry deciduous forests in Southem India. Tropical Ecology, 36, 117-127.

Wang, Y.C., 2011. Carbon sequestration and foliar dust retention by woody plants in the green belts along two major Taiwan Highways. Annals of Applied Biology, 159, 244-251. https://doi.org/10.1111/j.1744-7348.2011.00494.x

Yao, Z., Liu, J., Zhao, X., Long, D. and Wang, L., 2015. Spatial dynamics of aboveground carbon stock in urban green space: a case study of Xi'an, China. Journal of Arid Land, 7(3), 350-360. https://link.springer.com/article/10.1007/s40333-014-0082-9 (accessed on 4 April 2020). 